\title{
積雪寒冷地域におけるコンビニエンスストアの 店内温熱環境及び電力消費特性に関する研究 \\ INDOOR THERMAL ENVIRONMENT AND ELECTRICITY CONSUMPTION CHARACTERISTICS OF CONVENIENCE STORES IN SNOWY AND COLD REGIONS
}

\author{
菊田弘 輝 ${ }^{*}$, 田中優里香 ${ }^{*}$, 金子亮平 ${ }^{* *}$, 羽山広 文 ${ }^{* * * *}$
}

\author{
Koki KIKUTA, Yurika TANAKA, Ryohei KANEKO \\ and Hirofumi HAYAMA
}

\begin{abstract}
The Revised Law Concerning Energy Conservation Law was enforced, therefore it is necessary for convenience store (CVS) to reduce primary energy consumption. The aim of this study is to clarify the indoor thermal environment and electricity consumption characteristics of CVS in snowy and cold regions. The effects on temperature distribution by the differences in each temperature settings for merchandise management or air-conditioning system, etc. is analyzed. Ratio of electricity consumption and annual energy consumption per unit area are shown, and the valuation method of energy efficiency applicable to CVS is proposed.
\end{abstract}

Keywords: Convenience store, Prediction model of electricity consumption, Temperature distribution, Ratio of electricity consumption, Air-conditioning load コンビニエンスストア，電力消費予測モデル，温度分布，電力消費比率，空調負荷

\section{1.はじめに}

平成20年度省エネ法改正に伴い，これまでの事業所単位から事業 者単位（企業単位）のエネルギー管理が義務付けられている。一定 の要件を満たすフランチャイズチェーンは省エネ法の適用を受ける ため，企業努力が一層求められている，その1つのコンビニエンスス トア (CVS) は国内で約 4 万 5 千店舗 ${ }^{1}$ 展開され，一次エネルギー消費 原単位は用途別で飲食店に次いで大きいことが報告されている22。現 在，照明設備のインバータ化・調光制御・省エネタイプのIH調理器 具等が多くのCVSで標準化され，低炭素社会の実現に向けて環境配慮 型店舗や循環型店舗の開発が実験的に行われている. 特に3.11の東 日本大震苂以降, 節電・省エネ意識の高まりから, スマートメー ター・LED照明・太陽光発電等が新築・既存問わず積極的に導入され 始めている。

このようなCVSを取り巻く環境の変化に対し, 学術的な取り組みと して製造・販売・流通等の商学や経営学，立地・防犯等の地理学や 社会学が先行している. 一方, 環境工学における取り組みは未だ少 ない状況ではあるが，非住宅建築物の環境関連データベース2) 4)，坂 本らのCVSの省エネルギー化に関する研究5) 7)，小松らのCVSの泠暖房 負荷に関する研究8) 99)等で報告されている.
そこで, 本研究では既往研究では扱われていない積雪寒冷地域を 対象とし, CVSの店内温熱環境及び電力消費特性を明らかにすること を目的とする. 具体的には, (1)建築・設備仕様や運用状況を統計的 に整理し，電力消費量に対する要因分析に基づくCVSの電力消費予測 モデルを作成する. (2)CVS特有の商品管理上の各設定温度や空調方式 等の違いが及ぼす温度分布への影響を分析する. (3) CVS特有の電力消 費比率と年間エネルギー消費原単位を示し，CVSに適用可能なエネル ギー効率の評価方法を提案する. (4)地域性と実行性を考慮した上 で，空調負荷に焦点を当てて建築的対応かつ運用改善による削減効 果を定量化する．ちなみにCVSは独立店舗・ビルイン・店舗兼住宅の 3つの店舗形態に分類することができ, 最も一般的な独立店舗を中心 に報告し，季節区分は夏期を6〜9月，冬期を11〜4月とする.

\section{2. エネルギ一調査}

\section{1 調査概要}

札幌市内に立地するCVS（S社）の256店舗を対象に, 建築・設備仕 様や運用状況，電力消費量を調查した（表1）。本調查はGoogleス卜 リートビュー機能, S社が管理するデータ, 設計事務所が保管する図 面，店舗オーナーへのアンケートに基づいて実施している.

\footnotetext{
* 北海道大学大学院工学研究院 助教 ·博士 (工学)

** 北海道電力 $($ 株 $)$

$* * *$ 北海道大学大学院工学院 修士課程

**** 北海道大学大学院工学研究院 教授 - 博士 (工学)
}

Assist. Prof., Faculty of Eng., Hokkaido Univ., Dr. Eng.

Hokkaido Electric Power Co., Inc.

Graduate Student, Graduate School of Eng., Hokkaido Univ.

Prof., Faculty of Eng., Hokkaido Univ., Dr. Eng. 


\section{2 建築·設備仕様}

店舗形態では独立店舗が $54[\%]$ で最も多く, 以下ビルインが 24 [\%], 店舗兼住宅が22[\%]を占めていた. 正面方位（開口面積の大 きいファサード方位) は立地条件に左右され, 全方位で偏りなく分 布していた，正面方位に位置する扉は自動ドアよりも手動ドアの方 が多く, 戸建住宅で普及する玄関フードのような熱的な干渉空間は 一部のビルインに限られている.

築年数では 10 年以下の比較的新しい店舗が $64[\%]$ で多く, CVS特有 の出店・閉店サイクルが影響していた（図1）。主構造では独立店舗 で一般的な $\mathrm{S}$ 造が最も多く, $2 \times 4$ パネルとトラスを使用することで $200\left[\mathrm{~m}^{2}\right]$ 程度で柱のない木造も近年増加している.

売場・店舗面積は120～179[ $\left.\mathrm{m}^{2}\right] \cdot 160 \sim 219\left[\mathrm{~m}^{2}\right]$ の範囲に集中してお り，これは戸建住宅の平均延床面積の1.5倍程度に相当する（図 2）。断熱・開口仕様では全国画一の標準仕様が幅広く適用され，断 熱仕様は積雪寒冷地域の水準に達しておらず, 開口仕様ではシング ルガラス+アルミサッシが78[\%]を占めていた. 空調・受電方式で はダクト接続型・低圧受電が多く, 天井カセット型による省エネタ イプ+個別制御の導入も近年増加している (図3).

\section{3 運用状況}

アンケート調査に基づく空調設備運用について, 設定温度では中 央值が本部推奨值 (冷房 : $25\left[{ }^{\circ} \mathrm{C}\right]$, 暖房 : $21\left[{ }^{\circ} \mathrm{C}\right]$ ) に対し, $2\left[{ }^{\circ} \mathrm{C}\right]$ 程 度異なっていた. 特に夏期の $14 \sim 18$ 時は低く設定され, 店舗間の差 が最大で $8\left[{ }^{\circ} \mathrm{C}\right]$ に達していた（図4）。運転モードでは特に中間期に 各店舗で大きな違いが見られ, 冷房 $>$ 送風 $>$ 運転なし >ドライ>暖 房の大小関係を示した。また，夜間に冷房から送風または運転なし へ変更寸る店舗が比較的多かった（図5）。

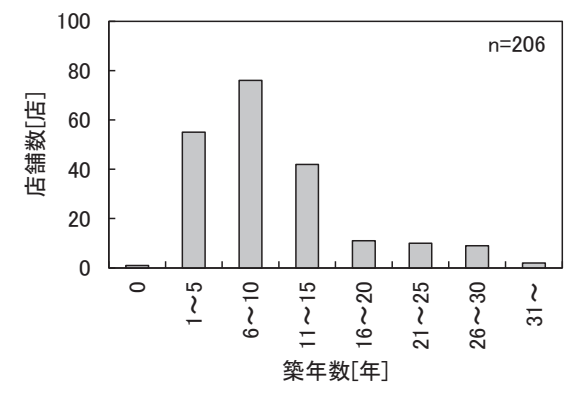

図1 築年数

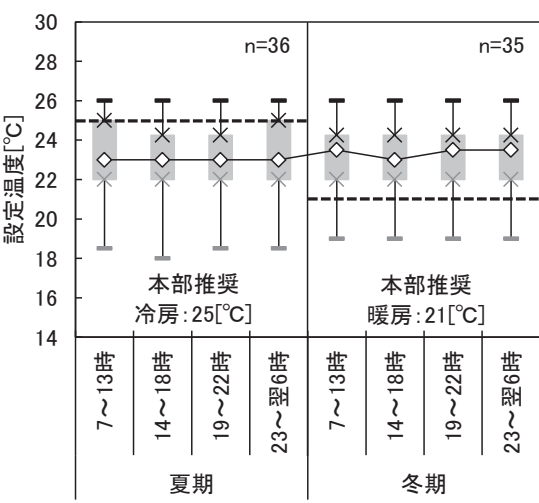

$\times$ 第3四分点 - 最大值 - 最小値

$\times$ 第1四分点 $\multimap$ 中央値

図4 設定温度

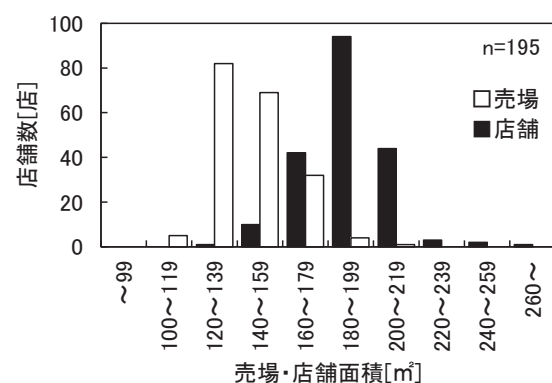

図2 売場・店舗面積

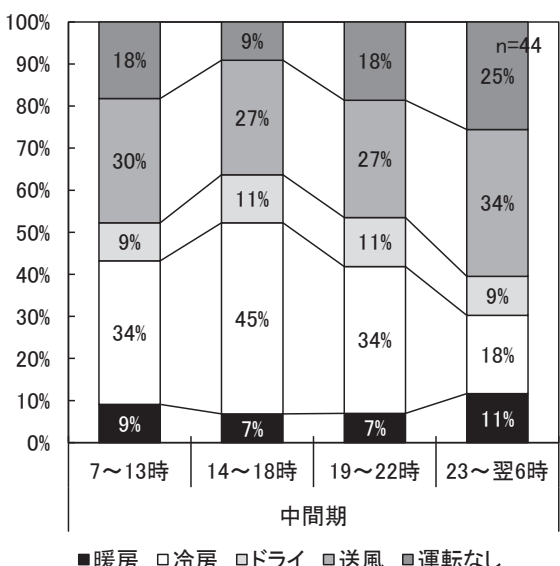

図5運転モード
表1 調查データ概要

\begin{tabular}{|c|c|c|}
\hline 項目 & 有効データ数n & 内容 \\
\hline 店舗 & 256 & 札幌 (2010/8/21時点) \\
\hline 店舗形態 & 231 & 独立店舗, ビルイン, 店舗兼住宅 \\
\hline 正面方位 & 231 & 開口面積の大きいファサード方位 \\
\hline 築年数 & 206 & \\
\hline 主構造 & 181 & S造, 木造, RC造, SRC造 \\
\hline 売場·店舗面積 & $195 \cdot 195$ & 事務所·倉庫等を含まない延床面積·含む延床面積 \\
\hline 断熱·開口仕様 & $114 \cdot 120$ & 天井, 壁, 床仕様·空仕様 \\
\hline 空調・受電方式 & $205 \cdot 208$ & ダクト接続型, 天井カセット型·高圧受電, 低圧受電 \\
\hline 空調設備運用 & 48 (最大) & 設定温度, 運転モ一ド等 \\
\hline 省エネ活動 & 50 (最大) & ブラインド開閉, 扉開閉等 \\
\hline 電力消費量 & 199 & $2009 / 4 \sim 2010 / 3$ (各月) \\
\hline
\end{tabular}

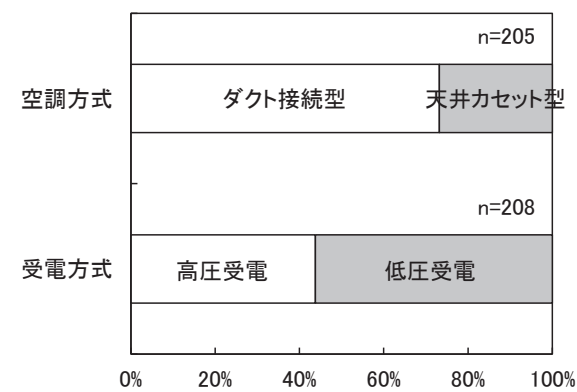

図3 空調・受電方式

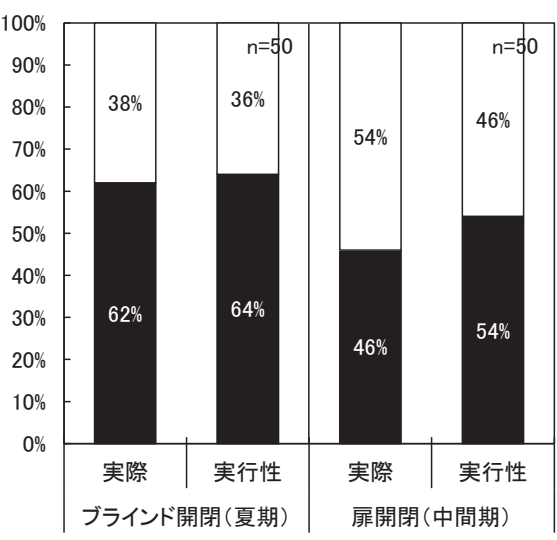

ロ行っている·できる ロ行っていない.できない

図6 省エネ活動 
店舗のばらつきは抑制され，冷暖房のピーク月となる 8 月の平均值は $92\left[\mathrm{kWh} / \mathrm{m}^{2}\right.$ ・月], 1 月の平均值は $96\left[\mathrm{kWh} / \mathrm{m}^{2} ・\right.$ 月]であった。 また, 2009 年度の年間電力消費量は平均で $1034\left[\mathrm{kWh} / \mathrm{m}^{2}\right.$ ・年 $]$, 店舗間の差は最大 で $487\left[\mathrm{kWh} / \mathrm{m}^{2}\right.$ ・年]であることが確認された．同じく独立店舗を対象と した年間電力消費量に対し, 築年数では全体の相関は弱かったが, 築8年以下の場合に最も強い相関を示し, 年数に応じて電力消費量の 増加が確認された（図8）. 対照的に店舗面積の増加に伴う電力消費 量の減少が確認され, $150\left[\mathrm{~m}^{2}\right]$ の場合に約 $1144\left[\mathrm{kWh} / \mathrm{m}^{2}\right.$ ・年 $], 200\left[\mathrm{~m}^{2}\right]$ の場合に2割減の $930\left[\mathrm{kWh} / \mathrm{m}^{2}\right.$ ·年]であった。

\section{5 電力消費量に対する要因分析}

電力消費量は各店舗で大きく異なることがわかり, 続いてその要 因を分析した．年間及び月間（冬期・夏期）の電力消費量を対象と し，これを目的変数とする重回帰分析を行った。これまでの建築・ 設備仕様や運用状況を説明変数とし, 空調・受電方式のみダミー変 数を用いている.

先ず説明変数の影響度を把握するため, 多重共線性を考慮しなが ら重回帰分析を行い，そこから得られる標準偏回帰係数を検証した （図9）。年間電力消費量では全店舗（Y1）と独立店舗（Y2）共に店 舗面積 (X2) が最も影響する要因であり, 以下空仕様 (X3) ・空調 方式 (X4) ・受電方式 (X5) の順に影響度が大きかった。 それに対 して月間電力消費量では冬期（Y3） と夏期（Y4）共に有意な説明変 数として外気温（X1）が加わり, その他にも店舗面積・空仕様が主 な要因であることが確認された.

\section{6 電力消費予測モデルの作成}

電力消費量に対する要因分析に基づくCVSの電力消費予測モデルを 作成した. 自由度調整済み決定係数及び判定結果から判断すると, Y 2 と Y 3 の予測精度が比較的高く, 説明変数に応じた偏回帰係数を用 いて重回帰式が立てられる（表2）。

$\mathrm{Y} 2=-4.60 \times 2-229.96 \times 3+157.40 \times 4+62.79 \times 5+1734.52$

$\mathrm{Y} 3=-1.28 \times 1-0.42 \times 2-20.15 \times 3+18.62 \times 4+5.02 \times 5+150.19$

これらの式に基づき, 標準仕様から寒冷地仕様一順次転換を図っ ていく際には, 空仕様の性能向上は重要である. しかし, ファサー ドの透過性の観点から高価な真空ガラスが一部で導入され, 建設コ ストの増加に繋がっている. 今後, 各店舗への波及効果が期待され るLow-Eペアガラス等も選択肢に加え, 電力消費量の削減に努めてい く必要がある.

\section{3. 実測調査}

\section{1 調査概要}

エネルギー調査を踏まえ, 標準仕様かつ寒冷地仕様双方の独立店 舗を対象に，店内温熱環境及び電力消費特性を調査した。対象店舗 は札幌市内に立地する標準仕様の店舗 $\mathrm{N}$, 寒冷地仕様の店舗 $\mathrm{S} の 2$ 店舗 である（表3）。なお電力消費量に対する要因分析で影響度が大き く, 店内温熱環境への影響が大きいと推測される空仕様・空調方式 の違いを重視して両店舗を選定した. 特に店舗Sでは木造, Low-Eぺ アガラス, 天井カセット型が導入され, 空調機の暖房能力（低温）
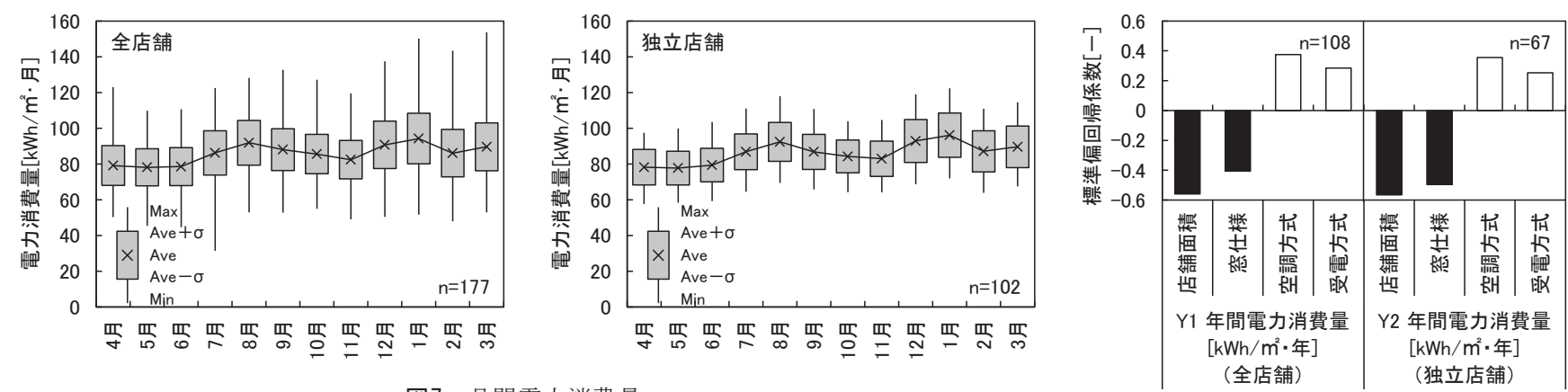

図7 月間電力消費量
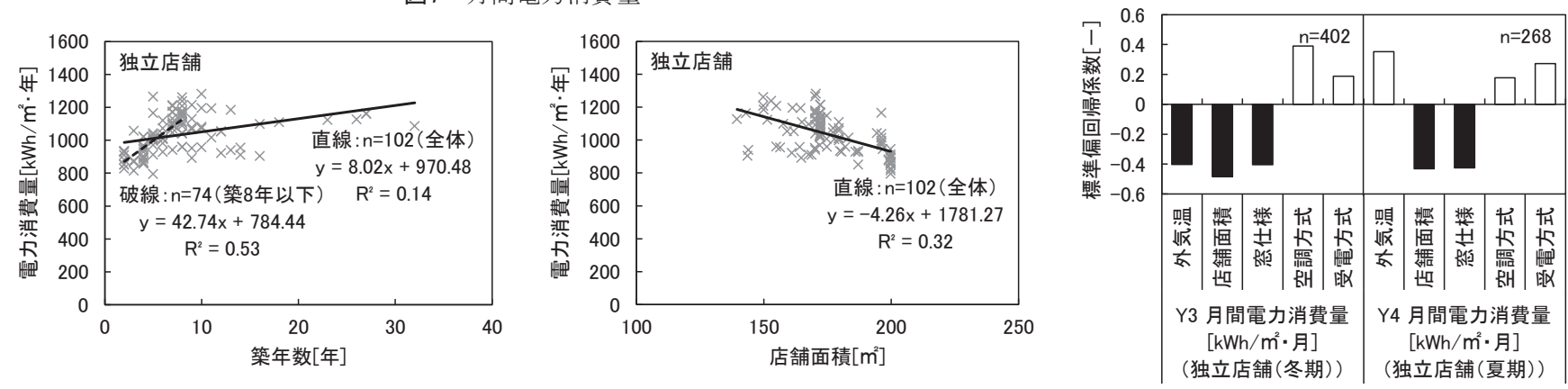

図8 築年数・店舗面積と年間電力消費量の関係

図9 標準偏回帰係数

表2 偏回帰係数

\begin{tabular}{|c|c|c|c|c|c|c|c|c|c|c|c|c|c|c|c|c|}
\hline \multirow{3}{*}{$\mathrm{Y} 1$ 年間電力消費量 $\left[\mathrm{kWh} / \mathrm{m}^{2} \cdot\right.$ 年 $]$} & \multicolumn{12}{|c|}{ 偏回帰係数 } & \multirow{2}{*}{\multicolumn{2}{|c|}{$\begin{array}{c}\text { 自由度 } \\
\text { 調整済み } \\
\text { 決定係数 }\end{array}$}} & \multirow{3}{*}{$\begin{array}{l}\text { 対象 } \\
\text { 全店舗 }\end{array}$} & \multirow{3}{*}{$\begin{array}{c}\text { サンプル } \\
\text { 数 } \\
108 \\
\end{array}$} \\
\hline & \multicolumn{2}{|c|}{$\begin{array}{c}\mathrm{X} 1 \text { 外気温 } \\
{\left[{ }^{\circ} \mathrm{C}\right]}\end{array}$} & \multicolumn{2}{|c|}{$\begin{array}{c}\text { X2 店舗面積 } \\
{\left[\mathrm{m}^{2}\right]}\end{array}$} & \multicolumn{2}{|c|}{$\begin{array}{l}\mathrm{X} 3 \text { 空仕様 } \\
{\left[\mathrm{m}^{2} \cdot \mathrm{K} / \mathrm{W}\right]}\end{array}$} & \multicolumn{2}{|c|}{$\begin{array}{c}\text { X4 空調方式 } \\
{[-]}\end{array}$} & \multicolumn{2}{|c|}{$\begin{array}{c}\text { X5 受電方式 } \\
{[-]}\end{array}$} & \multicolumn{2}{|c|}{ 定数項 } & & & & \\
\hline & $>$ & 1 & -4.13 & ** & -210.99 & ** & 102.56 & $* *$ & 65.82 & ** & 1693.98 & $* *$ & 0.52 & $* *$ & & \\
\hline $\mathrm{Y} 2$ 年間電力消費量 $\left[\mathrm{kWh} / \mathrm{m}^{2}\right.$ ·年] & 1 & $Z$ & -4.60 & $* *$ & -229.96 & $* *$ & 157.40 & $* *$ & 62.79 & $* *$ & 1734.52 & $* *$ & 0.68 & $* *$ & 独立店舗 & 67 \\
\hline $\mathrm{Y} 3$ 月間電力消費量 $\left[\mathrm{kWh} / \mathrm{m}^{2}\right.$ ·月] & -1.28 & $* *$ & -0.42 & $* *$ & -20.15 & ** & 18.62 & $* *$ & 5.02 & $* *$ & 150.19 & $* *$ & 0.66 & ** & 独立店舗 (冬期) & 402 \\
\hline $\mathrm{Y} 4$ 月間電力消費量 $\left[\mathrm{kWh} / \mathrm{m}^{2}\right.$ ·月] & 2.44 & $* *$ & -0.34 & $* *$ & -18.87 & $* *$ & 7.55 & $* *$ & 6.48 & $* *$ & 93.85 & $* *$ & 0.58 & $* *$ & 独立店舗 (夏期) & 268 \\
\hline 備考 & & & & & 空調方 & 定: & 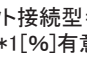 & & $\begin{array}{l}\text { 力セッ } \\
\text { 有意 }\end{array}$ & & 受電 & & $\begin{array}{l}\text { 電= } \\
\text { 的 }\end{array}$ & & & \\
\hline
\end{tabular}


は店舗よよりも優れている。この空調機は外気低温時に十分な性能を 発揮する寒冷地向けのパッケージェアコンであり, 通年エネルギー 消費効率（参考值）は5馬力140型で4. 9，6馬力160型で3.6である.

2009/8 2011/11の期間中, 店内と空調/天井吹出し口に温湿度計, 事務所内の分電盤に電力量計（パルス出力）を設置し，全て10分間 隔で測定した注1)（図10）。空調/天井吹出し口に関連して両店舗の空 調方式について説明する. 店舗Nのダクト接続型では1[台]の室内機 に6[本]の空調ダクトが接続され，5[本] は直接，1[本] は途中で3[本 $]$ に分岐して空調吹出し口に慗がっている. 店舗 $\mathrm{S} の 天$ 天井カセット型で は2[台]の室内機の内, 冷房時に店内入口（No. 19）の室内機, 暖房 時に店内奥（No. 17）の室内機が主に運転されている．また，空調と
連動したファンにより店内入口（No. 19）から吹出される冷温風の一 部がレジ内（No. 20）の空調吹出し口から店内一供給されている注2).

\section{2 店内温熱環境}

\section{2.1 各月の店内温度特性}

各月で温度差（計12[点]）が最大であった日の店内温度を箱钐図 の形で表記している（図11）。CVSの場合, 商品管理上の各設定温度 の違いにより温度分布への影響が懸念される中，店舗Nの温度差は8 $\left[{ }^{\circ} \mathrm{C}\right]$ 前後かつ最大で $10\left[{ }^{\circ} \mathrm{C}\right]$ 以上, 店舗 $\mathrm{S}$ 温度差は $5\left[{ }^{\circ} \mathrm{C}\right]$ 前後であるこ とが確認された。このような比較的狭い空間での温度分布の偏在は 冷蔵・冷凍や加温・調理で用いられる機器が多数混在するCVS特有の 店内温熱環境であると言える。
表3 店舖概要

\begin{tabular}{|c|c|c|c|c|c|}
\hline \multicolumn{2}{|l|}{ 店舗 } & \multicolumn{2}{|c|}{ 店埔N } & \multicolumn{2}{|c|}{ 店舗 $\mathrm{S}$} \\
\hline \multicolumn{2}{|c|}{ 竣工年 } & \multicolumn{2}{|c|}{ 2000年 } & \\
\hline \multirow{2}{*}{\multicolumn{2}{|c|}{$\begin{array}{l}\text { 所在地 } \\
\text { 店舗形態 }\end{array}$}} & \multirow{2}{*}{\multicolumn{2}{|c|}{$\begin{array}{c}\text { 札幌市東区 } \\
\text { 独立店㬨 }\end{array}$}} & \multirow{2}{*}{\multicolumn{2}{|c|}{$\frac{\text { 札幌市南区 }}{\text { 独立店舗 }}$}} \\
\hline & & & & & \\
\hline \multicolumn{2}{|c|}{ 正面方位 } & \multicolumn{2}{|c|}{ 北 } & \multicolumn{2}{|c|}{ 東 } \\
\hline \multicolumn{2}{|c|}{ 主構造 } & \multicolumn{2}{|c|}{ S造 } & \multicolumn{2}{|c|}{ 木造 } \\
\hline \multicolumn{2}{|c|}{ 売場·店舗面積 } & \multicolumn{2}{|c|}{$116.3\left[\mathrm{~m}^{2}\right] \cdot 177.3\left[\mathrm{~m}^{2}\right]$} & \multicolumn{2}{|c|}{$147.0\left[\mathrm{~m}^{2}\right] \cdot 200.0\left[\mathrm{~m}^{2}\right]$} \\
\hline \multicolumn{2}{|c|}{ 開口仕様 } & \multicolumn{2}{|c|}{ シングルガラス } & \multicolumn{2}{|c|}{ Low-Eペアガラス } \\
\hline \multicolumn{2}{|c|}{ 空調·受電方式 } & \multicolumn{2}{|c|}{ ダクト接続型·高圧受電 } & \multicolumn{2}{|c|}{ 天井カセット型·高圧受電 } \\
\hline \multicolumn{2}{|c|}{ 空調機 } & \multicolumn{2}{|c|}{$\begin{array}{l}\text { 室外機: 2[台] } \\
\text { (室内機: } 1 \text { [台] })\end{array}$} & \multicolumn{2}{|c|}{$\begin{array}{l}\text { 室外機: 2[台] } \\
\text { (室内機: 2[台]) }\end{array}$} \\
\hline \multicolumn{2}{|c|}{ 冷房能力[kW/台] } & 12.5 & 12.5 & $\begin{array}{c}12.5 \\
(5.7 \sim 14.0) \\
\end{array}$ & $\begin{array}{c}14.0 \\
(6.0 \sim 16.0) \\
\end{array}$ \\
\hline \multirow{2}{*}{$\begin{array}{l}\text { 暖房能力 } \\
{[\mathrm{kW} / \text { 台 }]}\end{array}$} & 標準 & 14.0 & 14.0 & \begin{tabular}{c|}
14.0 \\
$(5.0 \sim 20.1)$ \\
\end{tabular} & $\begin{array}{c}16.0 \\
(5.0 \sim 20.8) \\
\end{array}$ \\
\hline & 低温 & 12.7 & 12.7 & 16.4 & 18.0 \\
\hline \multicolumn{2}{|c|}{ 冷房消費電力[kW/台] } & 4.01 & 4.01 & 3.13 & 4.23 \\
\hline \multirow{2}{*}{$\begin{array}{c}\text { 暖房消費電力 } \\
{[\mathrm{kW} / \text { 台 }]}\end{array}$} & 標準 & 3.83 & 3.83 & 3.10 & 4.42 \\
\hline & 低温 & 6.62 & 6.62 & 3.10 & 4.42 \\
\hline
\end{tabular}

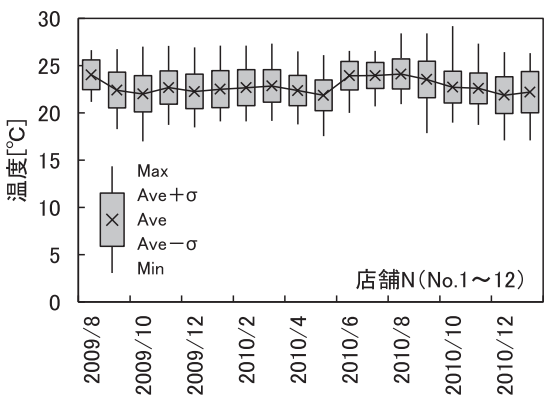

図11 各月の店内温度特性
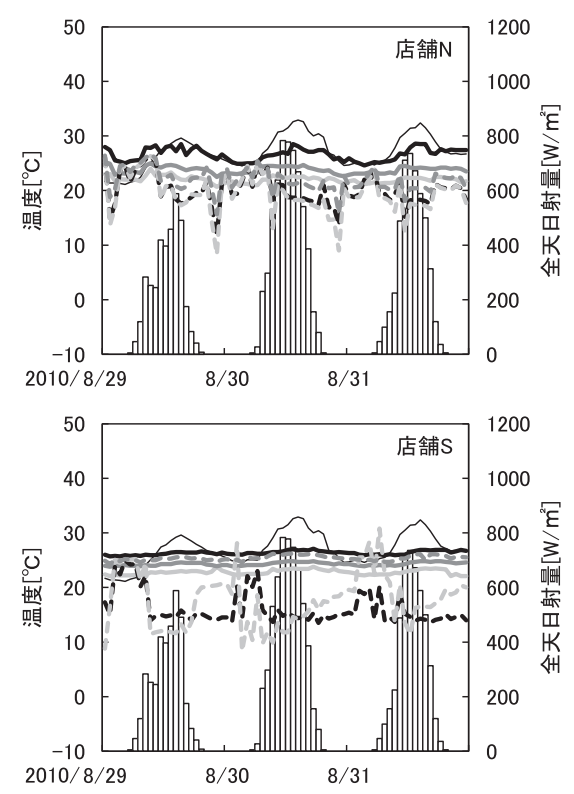

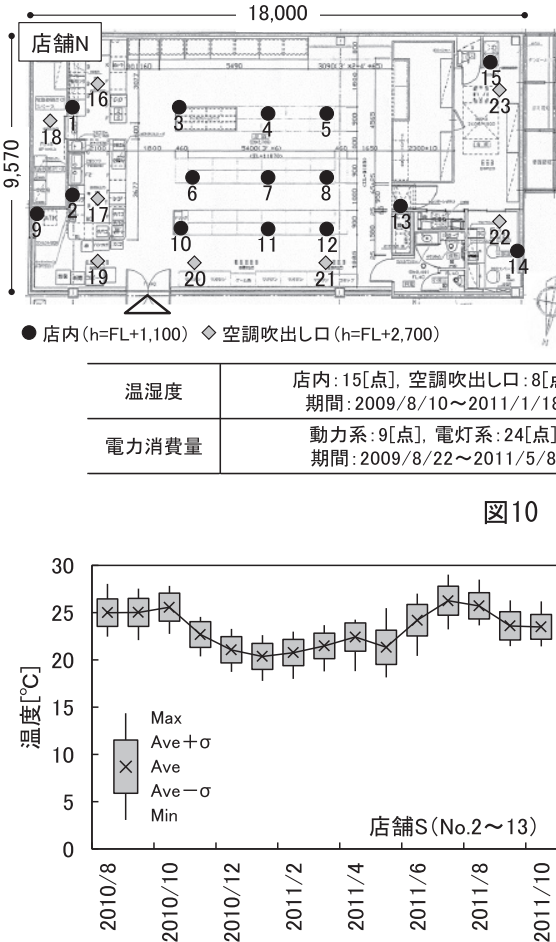

図10 測定概要
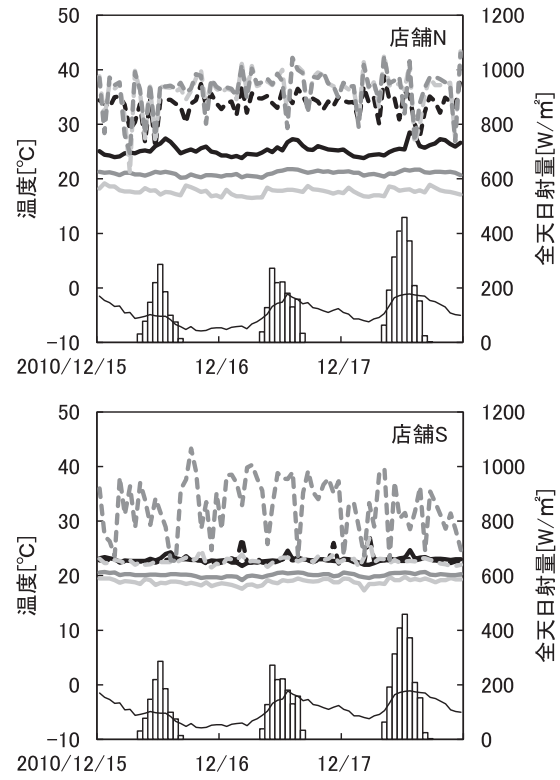

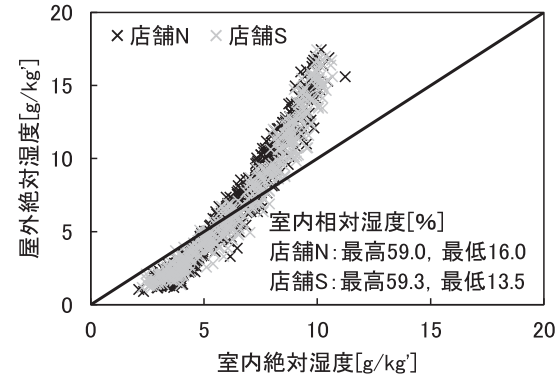

図12 絶対湿度

$\square$ 水平面
屋外
No.12レジ内
No.8アイスケース付近
No.4店内中央
-- No.20レジ内
-- No.19店内入口
※破線: 空調吹出し口

\begin{tabular}{|c|c|c|c|c|}
\hline & \\
\hline & \multicolumn{2}{|c|}{ 店舗 $\mathrm{N}$} & $\begin{array}{l}2010 / \\
8 / 29 \sim \\
8 / 31\end{array}$ & $\begin{array}{l}2010 / \\
12 / 15 \sim \\
12 / 17\end{array}$ \\
\hline \multirow{2}{*}{$\begin{array}{l}\text { 水平面 } \\
\text { 屋外 }\end{array}$} & \multirow{3}{*}{ 屋外 } & 最高 & 32.9 & -1.1 \\
\hline & & 平均 & 27.0 & -4.6 \\
\hline \multirow{3}{*}{$\begin{array}{l}\text { No.1レジ内 } \\
\text { No.3アイスケース付近 } \\
\text { No.7店内中央 }\end{array}$} & & 最低 & 21.1 & -7.9 \\
\hline & \multirow[b]{2}{*}{$\begin{array}{l}\text { No.1 } \\
\text { レジ内 }\end{array}$} & 最高 & 28.6 & 28.5 \\
\hline & & 平均 & 26.6 & 25.4 \\
\hline \multirow{5}{*}{$\begin{array}{l}-- \text { No.16レジ内 } \\
\text { ※破線: 空調吹出しロ }\end{array}$} & \multirow{3}{*}{$\begin{array}{l}\text { No.3Pイス } \\
ケ-\text { ス付近 }\end{array}$} & 最高 & 24.0 & 19.2 \\
\hline & & 平均 & 22.0 & 17.7 \\
\hline & & & 20.7 & 16.5 \\
\hline & \multirow{3}{*}{$\begin{array}{c}\text { No.7 } \\
\text { 店内中央 }\end{array}$} & 最高 & 25.2 & 21.8 \\
\hline & & 平均 & 23.8 & 21.0 \\
\hline \multirow{4}{*}{$\begin{array}{c}{ } \text { 水平面 } \\
\text { 屋外 }\end{array}$} & & 取低 & 22.5 & 20.2 \\
\hline & \multicolumn{2}{|c|}{ 店埔S } & $\begin{array}{l}2010 / \\
8 / 29 \sim \\
8 / 31\end{array}$ & $\begin{array}{l}2010 / \\
12 / 15 \sim \\
12 / 17\end{array}$ \\
\hline & \multirow{3}{*}{ 屋外 } & 最高 & 32.9 & -1.1 \\
\hline & & 平均 & 27.0 & -4.6 \\
\hline \multirow{4}{*}{$\begin{array}{l}\text { No.12レジ内 } \\
\text { No.8アイスケース付近 } \\
\text { No.4店内中央 }\end{array}$} & & 最低 & 21.1 & -7.9 \\
\hline & \multirow{3}{*}{$\begin{array}{l}\text { No.12 } \\
\text { レシジ内 }\end{array}$} & 最高 & 27.1 & 24.7 \\
\hline & & 平均 & 26.3 & 22.9 \\
\hline & & 最低 & 25.7 & 21.8 \\
\hline -- No.20レジ内 & \multirow{3}{*}{$\begin{array}{l}\text { No.8ア1ス } \\
ケ-\text { 付近 }\end{array}$} & 最高 & 23.8 & 19.8 \\
\hline$=-$ No.19店内入口 & & 平均 & 22.8 & 18.9 \\
\hline \multirow{2}{*}{ - No.17店内奥 } & & 最低 & 22.1 & 17.3 \\
\hline & \multirow{3}{*}{$\begin{array}{c}\text { No.4 } \\
\text { 店内中央 }\end{array}$} & 最高 & 24.8 & 20.7 \\
\hline \multirow{2}{*}{ ※破線: 空調吹出しロ } & & 平12 & 24.3 & 20.2 \\
\hline & & & 23.8 & 19.2 \\
\hline
\end{tabular}
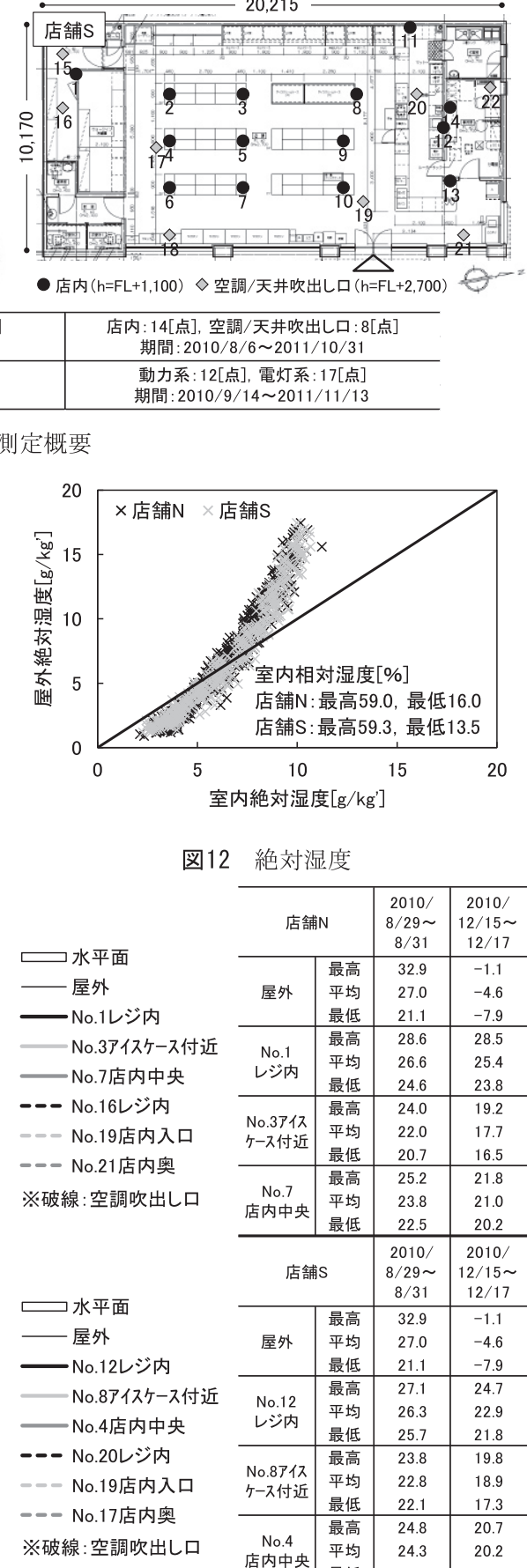

図13 代表日の店内温度変動 
店舗Sの平均温度は20〜 $26\left[{ }^{\circ} \mathrm{C}\right]$ を推移しており，ばらつきも小さく 季節に応じて変動していた. それに対して店舗Nの平均温度は $22 \sim 24$ $\left[{ }^{\circ} \mathrm{C}\right]$ で店舗Sに比べ夏期に低く冬期に高かった．これは極端に温度の 高いあるいは低い場所が形成され，その偏在に対応した空調により 平均温度が下がったあるいは上がったためである，従って，基本的 な仕様の違いに加え, 空調制御の違い（店舗N：一括制御，店舗 $\mathrm{S}$ ： 個別制御）も影響していたと考えられる.

測定期間中の絶対湿度は夏期に屋外 $>$ 室内，冬期に屋外 $<$ 室内の 大小関係を示したが，冬期に相対湿度が10[\%]台まで低下してお り，一時的に低湿度環境が形成されていた（図12）。

\section{2.2 代表日の店内温度変動}

店内温度はレジ内で最も高くアイスケース付近で最も低かった （図13）。この傾向は両店舗かつ両代表日で共通しており，特に店 舗Nのレジ内（No. 1）では2010/8/31の13時に最高で28.6[ $\left[{ }^{\circ} \mathrm{C}\right]$ に達し

\begin{tabular}{|c|c|c|c|}
\hline \multicolumn{2}{|l|}{ 店舗N } & \multicolumn{2}{|l|}{ 店舗S } \\
\hline \multicolumn{2}{|l|}{ 【動力系】 } & \multicolumn{2}{|l|}{ 【動力系】 } \\
\hline 機器 & 分類 & 機器 & 分類 \\
\hline $\begin{array}{l}\text { リーチインチルドケース } \\
\text { アイスクリームケース } \\
\text { ドリンク }\end{array}$ & 冷蔵·冷凍 & \multirow{4}{*}{$\begin{array}{l}\text { チルドウォクインン冷凍機 } \\
\text { 冷凍リーチイン } \\
\text { 栄養ドリンンクケース } \\
\text { アイスクリームケース(大) } \\
\text { アイスクリームケース (小) } \\
\text { アイランドチルドケース } \\
\end{array}$} & \multirow{4}{*}{ 冷蔵·冷凍 } \\
\hline $\mathrm{H} \& \mathrm{C}$ ケース & 加淐，調理 & & \\
\hline フライヤー & 加温・調埋 & & \\
\hline 空調機 & \multirow{3}{*}{ 空調 } & & \\
\hline 空調機 & & \multirow{2}{*}{$\begin{array}{c}\text { マルチケース(ヒーター) } \\
\text { フライヤー }\end{array}$} & \multirow{2}{*}{ 加温·調理 } \\
\hline 【電灯系】 & & & \\
\hline 機器 & 分類 & \multirow{2}{*}{$\begin{array}{l}\text { 空調機 } \\
\text { 空調機 }\end{array}$} & \multirow{2}{*}{ 空調 } \\
\hline 低温リー千イ & \multirow{4}{*}{$\begin{array}{c}\text { 冷設照明· } \\
\text { ファン }\end{array}$} & & \\
\hline オープンケース & & \multicolumn{2}{|l|}{ 【電灯系】 } \\
\hline ウォークイ & & \begin{tabular}{|c|} 
機器 \\
\end{tabular} & 分類 \\
\hline リーチイン・オープンケース照明 & & \multirow{2}{*}{$\begin{array}{c}\text { 低温リーチイン(フアン・ヒーター) } \\
\text { オープンケース(フアン・ヒーター) } \\
\text { ウオークイイ(フアン・ヒーター) } \\
\text { 冷凍冷蔵照明 }\end{array}$} & \multirow[b]{2}{*}{$\begin{array}{l}\text { 冷設照明· } \\
\text { ファン }\end{array}$} \\
\hline $\begin{array}{c}\text { 温水器 } \\
\text { カウンターゴト (肉まんヒーター) } \\
\text { カウンターコンセント(おでんウォーマー奥) }\end{array}$ & \multirow{3}{*}{ レジ販売 } & & \\
\hline 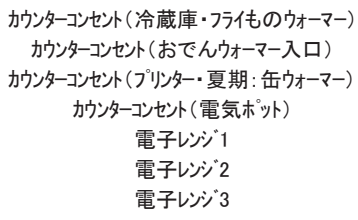 & & $\begin{array}{c}\text { 温水器 } \\
\text { A-1 カウンター什器 } \\
\text { B-1カウンター什器 } \\
\text { C-1カウンター什器 } \\
\text { E-1バックカウンター什器 } \\
\text { B-2電子レンジ } \\
\text { 業務用冷凍庫 } \\
\end{array}$ & レジ販売 \\
\hline フライヤー換気扇·冷凍庫 & & \multirow{2}{*}{$\begin{array}{c}\text { 事務所調理室照明 } \\
\text { サインポール } \\
\text { 店内照明 (奥側) } \\
\text { 店内照明 (入口側 })\end{array}$} & \multirow[b]{2}{*}{ 照明 } \\
\hline $\begin{array}{l}\text { 店内照明(前) } \\
\text { 店内照明(中) } \\
\text { 店内照明(奥) }\end{array}$ & \multirow{3}{*}{ 照明 } & & \\
\hline $\begin{array}{c}\text { 事務所·倉庫照明 } \\
\text { 店頭看板 }\end{array}$ & & $\begin{array}{l}\text { 낭- } \\
\text { ATM }\end{array}$ & サービス \\
\hline サイン゚ール & & 2 & 電灯その他 \\
\hline $\begin{array}{c}\text { ATM } \\
M \cdot \mathrm{COPY} \\
\end{array}$ & $\begin{array}{c}\text { サービス } \\
\text { 電灯その他 }\end{array}$ & \multicolumn{2}{|c|}{$\begin{array}{c}\text { 備考: 電灯その他=電灯全体一 } \\
\text { (冷設照明·ファン+レジ販売+ } \\
\text { 照明+サービス) }\end{array}$} \\
\hline
\end{tabular}

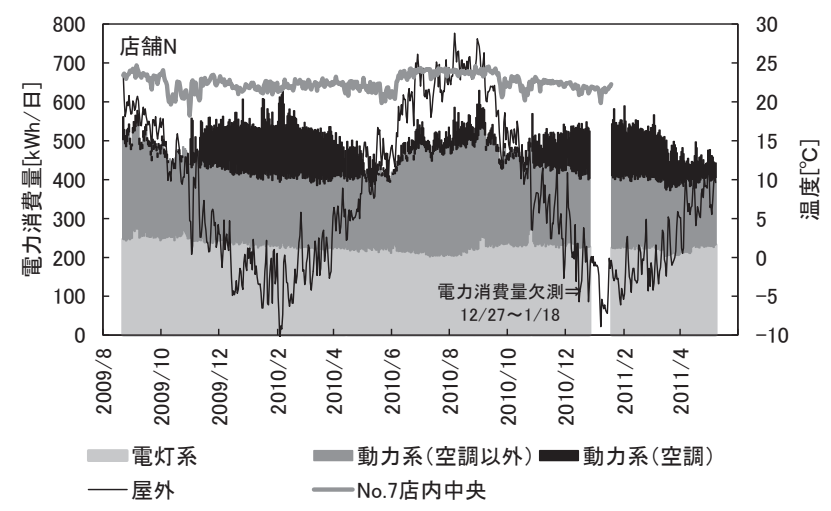

ていたため，従業員にとって暑い店内温熱環境であったと推測され る。また，店舗Sの空調吹出し口温度はレジ内（No. 20）と店内入口 (No. 19）では夏期に $15\left[{ }^{\circ} \mathrm{C}\right]$ 前後，店内奥（No. 17）では冬期に約 40 $\left[{ }^{\circ} \mathrm{C}\right]$ で個別制御され, 店舗Nに比べ良好な店内温熱環境が形成されて いた.

\section{3 電力消費特性}

\section{3.1 外気温と電力消費量の関係}

通常CVSの電力系統は200[V]動力系と $100[\mathrm{~V}]$ 電灯系に分けられ, 本 研究では動力系を「冷蔵・冷凍, 加温・調理, 空調」, 電灯系を 「冷設照明・ファン, レジ販売, 照明, サービス, 電灯その他」に 分類した（表4）.

その中で特にリーチインチルド（アイス・ドリンク類を除く冷 凍・冷蔵）と空調機（空調）の電力消費量は外気温に応じて増減し ていた（図14）。リーチインチルドは外気温の上昇で2倍以上，更に $15 \sim 20\left[{ }^{\circ} \mathrm{C}\right]$ で急激に増加していた. 空調機は $30\left[{ }^{\circ} \mathrm{C}\right]$ の泠房条件下と-

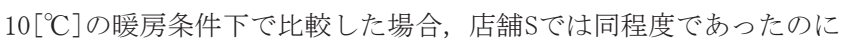
対し，店舗Nでは約2倍の差が生じていた.

\section{3.2 系統別の電力消費量}

電灯系の電力消費量は比較的軽微な季節変動であり, 店舗Nでは $250[\mathrm{kWh} /$ 日]前後, 店舗Sでは200[kWh/日]前後を推移していた注3) (図 15）。その電灯系に季節変動を伴う動力系を空調と空調以外に分け て積算すると, 店舗Nでは夏期のピーク時（2010/9/1）に629[kWh/ 日]，冬期のピーク時 $(2010 / 2 / 6)$ に $626[\mathrm{kWh} /$ 日]を記録していた。対 照的に店舗Sでは夏期のピーク時（2011/9/1）に580[kWh/日]で店舗N よりも僅かに少なかったのに対し, 積雪寒冷地域で懸念される冬期 のピーク電力は店舗Nの7割程度に抑えられていた。ちなみに2[台]合 わせた暖房消費電力のカタログ值が $7.52[\mathrm{~kW}]$ において, ピーク消費 電力は5.94[kW]であった。

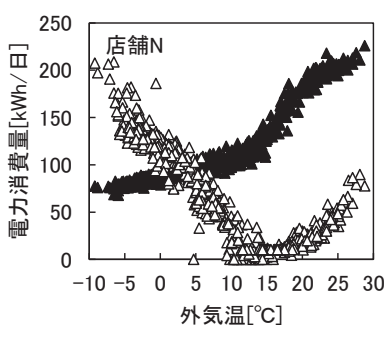

ムリーチインチルド $\Delta$ 空調機

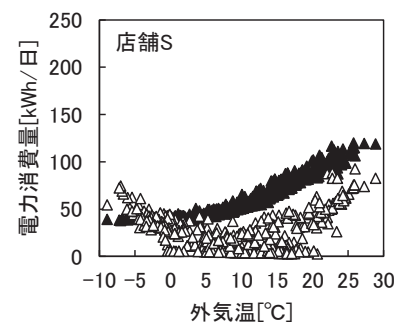

ムリーチインチルド $\Delta$ 空調機
図14 外気温と電力消費量の関係

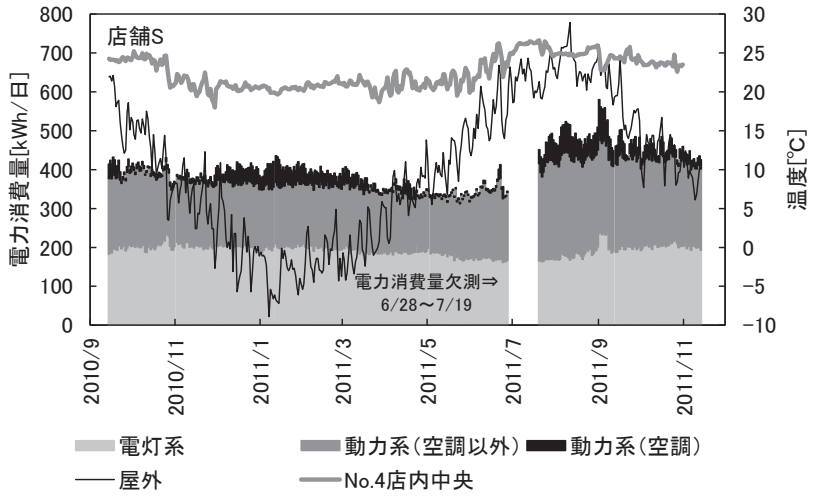

図15 系統別の電力消費量 


\section{3.3 系統別 ·分類別 - 機能別の電力消費比率}

1月・8月及び年間の電力消費比率を示し，これまでの系統別・分 類別に加え, 本研究では新たに必要機能と一般機能の機能別に分け て分析した注4) (図16, 図17）。必要機能とは, CVSの運営上, 安全な 商品管理に必要な設備「冷蔵・冷凍, 加温・調理, 冷設照明・ファ ン, レジ販売」, 一般機能とは, それ以外の設備「空調, 照明, サービス, 電灯その他」である.

店舗Nでは1月・8月の電力消費量が $95\left[\mathrm{kWh} / \mathrm{m}^{2}\right.$ ・月] 前後（動力系 : 電 灯系 $=6: 4)$ であった. しかし, 冷凍・冷蔵と空調は互いに変化し ており，1月の一般機能と必要機能は50[\%]前後で並んでいた。一
方，店舗 $\mathrm{S} て ゙ は 8$ 月店舗 $\mathrm{N}$ と同じ傾向であったが，1月は空調の違い で動力系が約7 [\%]少なかった. その結果, 年間の電力消費比率は系 統別では動力系が僅かに上回り, 分類別では空調が全体に影響を与 え，機能別では必要機能が全体の $2 / 3$ 程度を占めることがわかった。

\section{3 .4 年間エネルギー消費原単位}

年間エネルギー消費量と消費原単位を示し, 両店舗の位置付け把 握するため, 独立店舗（n=102）と住宅（2006年）10)を合わせて比較 した（図18）。なお住宅のエネルギーと合わせて二次エネルギー換 算とした。店舗Nは独立店舗の平均的な消費原単位（約 $3.7\left[\mathrm{GJ} / \mathrm{m}^{2}\right.$. 年]），店舗Sはその3割減（約 $2.6\left[\mathrm{GJ} / \mathrm{m}^{2}\right.$ •年]）に位置しており，CVS

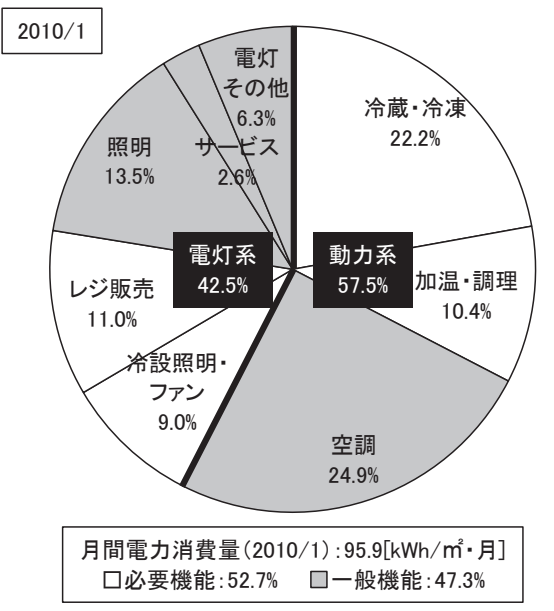

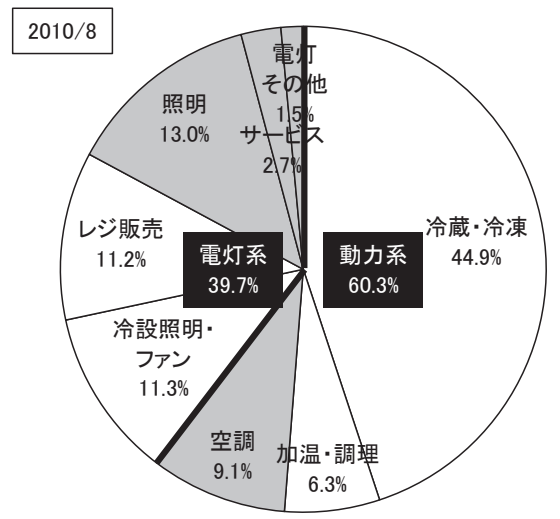

月間電力消費量 $(2010 / 8): 94.4\left[\mathrm{kWh} / \mathrm{m}^{2}\right.$ ·月] 口必要機能: $73.8 \% \quad \square$ 一般機能: $26.2 \%$

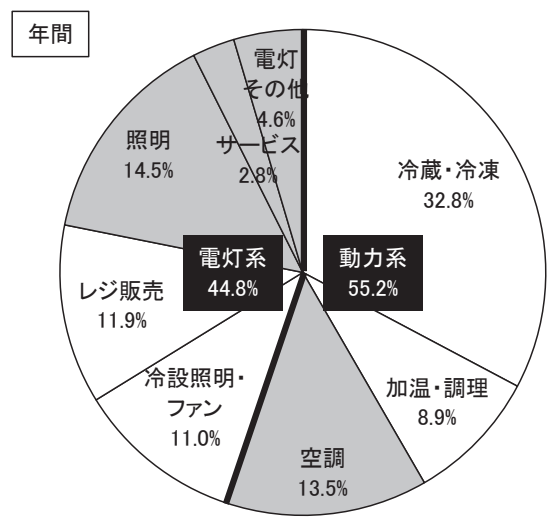

年間電力消費量: $1043.1\left[\mathrm{kWh} / \mathrm{m}^{2}\right.$ ·年] 口必要機能: $64.6 \% \quad \square$ 一般機能: $35.4 \%$

図16 系統別 - 分類別 - 機能別の電力消費比率 (店舗 $\mathrm{N}$ )
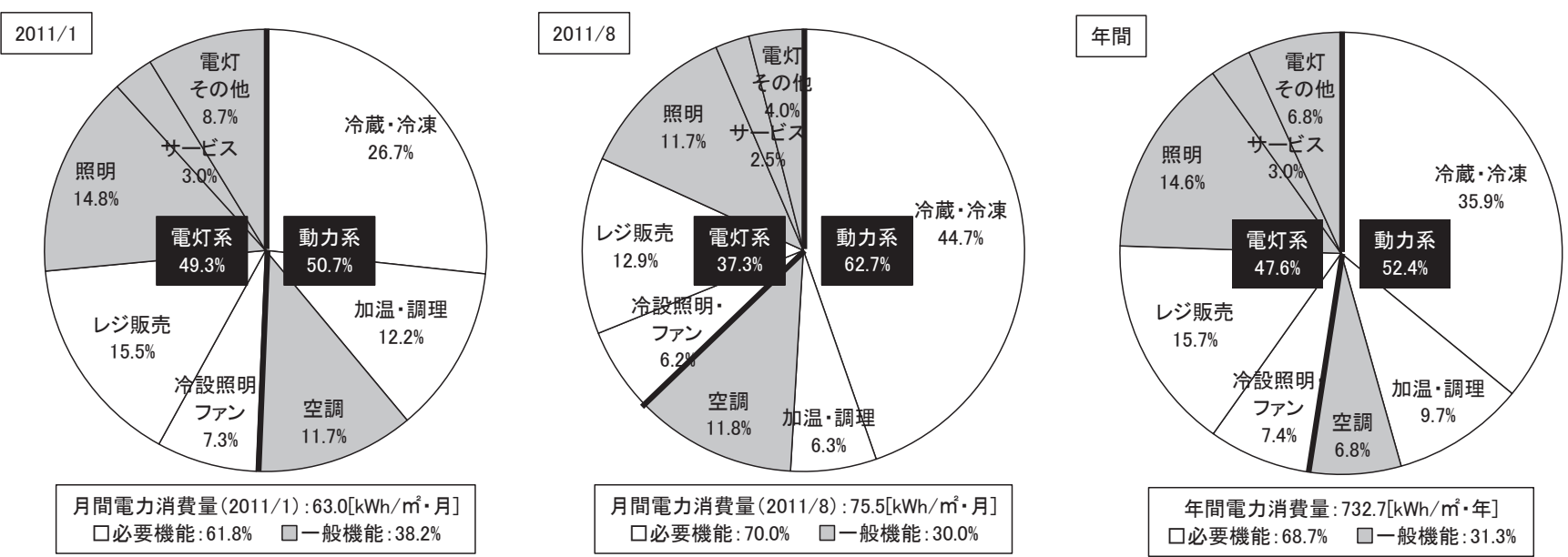

年間電力消費量 : $732.7\left[\mathrm{kWh} / \mathrm{m}^{2} \cdot\right.$ 年] 口必要機能: $68.7 \% \quad \square$ 一般機能: $31.3 \%$

図17 系統別 - 分類別 - 機能別の電力消費比率（店舗S）

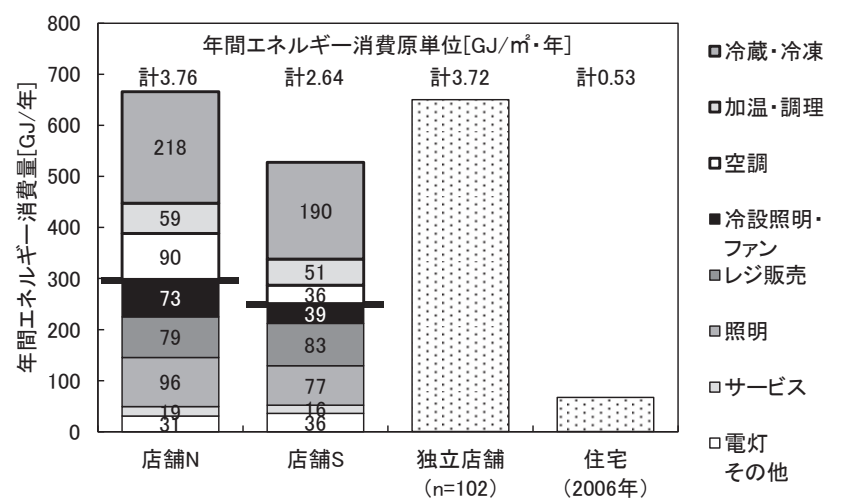

図18 年間エネルギー消費量と消費原単位

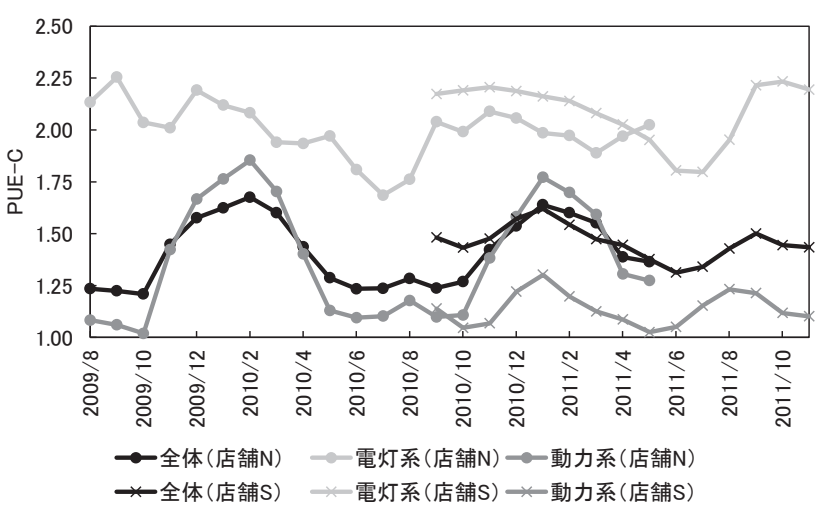

図19 エネルギー効率 (PUE-C) 
の消費量は住宅の8～10倍，消費原単位は5〜7倍に相当していた。た だし, 一次エネルギー換算あるいは $\mathrm{CO}_{2}$ 換算の場合, CVS と住宅が消費 するエネルギー種別（電力・ガス・灯油等）の違いにより一段と両 者の差が大きくなると考えられる.

\section{3.5 エネルギー効率}

更なる省エネを追求するためには，特に既存のCVSが省エネ性の高 い店舗または低い店舗なのかを判断する必要がある. 一般的に消費 原単位が平均に比べ大きければ，省エネすべき店舗として位置付け られるが，各店舗で異なる来客数や売上を考慮すると，本当に省工 ネすべき店舗かどうかを判断することは難しいと考えられる，そこ で，絶対的な消費原単位と合わせてPUE (Power Usage Effectiveness）11)を参考に相対的な効率で評価することを試みた.

PUEとは，一般的にデータセンター（DC）に適用されるエネルギー 効率を表す指標の1つである. $「 \mathrm{PUE}=\mathrm{DC}$ 全体の電力消費量 $/ \mathrm{DC}$ 内の $\mathrm{IT}$ 機器の電力消費量」と定義されている. PUEが1に近いほど, DC内の IT機器以外（主に空調）の電力消費量の割合が少なく, エネルギー 効率の良いDCを意味する，従って，その効率が大きければ，DC内の IT機器以外での省エネ化を一層図るべきということが明確になるた め, PUEは消費原単位とは違った役割を果たす。

そして今回新たに「PUE-C $=\mathrm{CVS}$ 全体の電力消費量 $/ \mathrm{CVS}$ 内の必要機 能の電力消費量」注5)を定義し, CVSに適用可能なエネルギー効率の評 価方法を提案した（図19）。PUE-Cが1に近いほど，CVS内の一般機能 （主に空調，照明）の電力消費量の割合が少なく，エネルギー効率 の良いCVSを意味する．PUEと同様，その効率が大きければ，CVS内の 一般機能での省エネ化を一層図るべきということが明確になる．両 店舗を比較した結果, 店舗Nでは冬期の動力系PUE-C注6) が非常に大き く, 店舗Sでは電灯系PUE-C注6) が若干大きかった。 全体PUE-C（一般機 能の省エネ化指標）は季節に応じて変動しながら $1.2 〜 1.7$ 範囲に なり，ピークをむかえる冬期を中心に積雪寒冷地域におけるCVSとし ての対策が求められる、今後, スマートメーター等で詳細にデータ を収集し, 地域毎の平均的なPUE-Cを明確にすることで各店舗で必要 なエネルギー削減に向けた対策を打つことが可能になる.

表5 基準モデルの計算条件

\begin{tabular}{|c|c|c|c|}
\hline 項目 & 条件 & & 室1(売場) \\
\hline 参考 & 店舗N & 室容積 & $464.81\left[\mathrm{~m}^{3}\right]$ \\
\hline 計算地点 & 札幌 & \multirow{3}{*}{ 内部発熱 } & \multirow{3}{*}{$\begin{array}{c}\text { 照明: } 2592[\mathrm{~W} / \mathrm{h}] \\
\text { 在室者: } 1031.6[\text { 人 } / \text { 日 }] \\
\text { 機器: } 893.5[\mathrm{~W} / \mathrm{h}]\end{array}$} \\
\hline プログラム & SMASH for Windows Ver.2.1 & & \\
\hline 気象データ & SMASH用気象データ & & \\
\hline 計算期間 & $1 / 1 \sim 12 / 31$ & 換気回数 & 1.21[回/h](機械+自然換気) \\
\hline 冷房期 & $6 / 5 \sim 9 / 5$ & 設定温度 & 冷房: $25\left[{ }^{\circ} \mathrm{C}\right]$, 暖房: $21\left[{ }^{\circ} \mathrm{C}\right]$ \\
\hline 中間期 & $5 / 1 \sim 6 / 4,9 / 6 \sim 10 / 9$ & \multicolumn{2}{|r|}{ 室2(屋根裏) } \\
\hline 暖房期 & $10 / 10 \sim 4 / 30$ & 室容積 & $185.92\left[\mathrm{~m}^{3}\right]$ \\
\hline
\end{tabular}
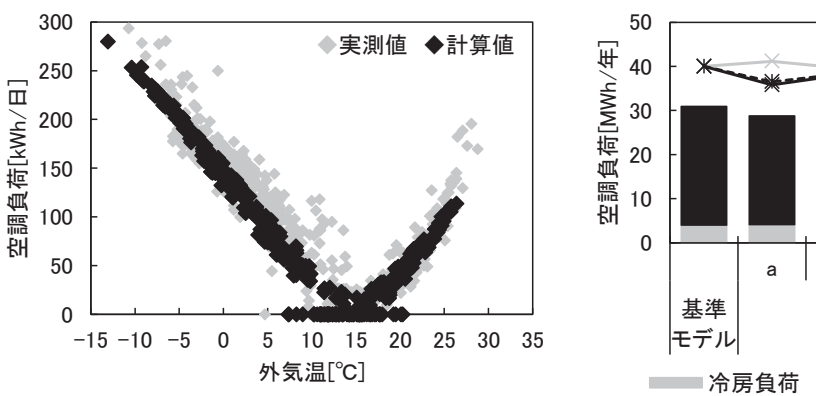

図20

実測值と計算值の比較

\section{4. 数值シミュレーション}

4.1 シミュレーション概要

一連の調査を踏まえ, 数值シミュレーションでは空調負荷に焦点 を当てて建築的対応かつ運用改善による削減効果を定量化した. 店 舗Nを参考に基準モデルを作成し，売場（24時間空調）と屋根裏の2 室モデルを想定した（表5）。また，エネルギー調査で示した本部推 奨值より冷房は $25\left[{ }^{\circ} \mathrm{C}\right]$ 設定, 暖房は $21\left[{ }^{\circ} \mathrm{C}\right]$ 設定とし, 内部発熱等は 店舗Nのデータに加え, 既往研究5) 7) に基づいている. 熱負荷計算プ ログラムは「SMASH for Windows Ver.2.1」を使用したが，その前提 として実測值と計算值の整合性を確認する必要がある。その際に, 空調負荷で両者を比較するため, 店舗Nの電力消費量に対して外気温 に応じた成績係数を乗じて得られたものを実測值とした，その結 果，店舗Nと基準モデルの空調負荷は概ね一致していたため，整合性 は十分に取れていると判断した（図20）。

\section{2 空調負荷削減効果}

空調負荷削減に向けた対策は地域性と実行性を考慮した上で，断 熱・開口・換気・運用・総合の5つの対策13パターン $(\mathrm{a} \sim \mathrm{m})$ を設定 した（表6）。断熱及び開口対策では暖房負荷が削減された一方，逆 に冷房負荷は増加したが，結果的に全負荷増減率は暖房負荷並みに 減少した（図21）。特にLow-Eペアガラス（e）を導入した場合，基 準比の約75[\%]に到達しており，既存のCVSにとって有効な対策の1 つであると言える，換気対策では熱交換換気（h）を導入することで 約17[\%]の削減効果をもたらし，運用対策では冷暖房期間（k）の短 縮に比べ設定温度（j）の変更が効果的であった。最終的に各対策を

表6 空調負荷削減に向けた対策

\begin{tabular}{|c|c|c|c|}
\hline \multirow{5}{*}{\multicolumn{2}{|c|}{$\begin{array}{l}\text { 基準 } \\
\text { モデル }\end{array}$}} & 項目 & 断熱仕様 \\
\hline & & \multirow{2}{*}{ 外壁 } & 厚さ $\mathrm{d}=35[\mathrm{~mm}]$, 熱伝導率 $\lambda=0.021[\mathrm{~W} / \mathrm{m} \cdot \mathrm{K}]$ (平面部) \\
\hline & & & $\mathrm{d}=35[\mathrm{~mm}], \lambda=0.041[\mathrm{~W} / \mathrm{m} \cdot \mathrm{K}]($ 嵌込部 $)$ \\
\hline & & 屋根 & $\mathrm{d}=25 \& 35[\mathrm{~mm}], \lambda=0.038 \& 0.026[\mathrm{~W} / \mathrm{m} \cdot \mathrm{K}]$ \\
\hline & & 床下 & $\mathrm{d}=25[\mathrm{~mm}], \lambda=0.038[\mathrm{~W} / \mathrm{m} \cdot \mathrm{K}]$ \\
\hline & & 基礎 & \\
\hline & & 空 & 熱貫流率U $=5.9\left[\mathrm{~W} / \mathrm{m}^{2} \cdot \mathrm{K}\right]$, 遮蔽係数 $\mathrm{SC}=1.00[-]$ \\
\hline 対 & & 項目 & \begin{tabular}{|l} 
断熱仕様·その他 \\
\end{tabular} \\
\hline & $\mathrm{a}$ & 外壁 & $\mathrm{d}=100[\mathrm{~mm}], \lambda=0.038[\mathrm{~W} / \mathrm{m} \cdot \mathrm{K}]$ \\
\hline & $\mathrm{b}$ & 屋根 & $\mathrm{d}=100[\mathrm{~mm}], \lambda=0.038[\mathrm{~W} / \mathrm{m} \cdot \mathrm{K}]$ \\
\hline 断熱 & c & 土間床 & $\mathrm{d}=50[\mathrm{~mm}], \lambda=0.040[\mathrm{~W} / \mathrm{m} \cdot \mathrm{K}]($ 床下 $\cdot$ 基礎 $)$ \\
\hline & $d$ & 2 & $a+b+c$ \\
\hline 開口 & $\mathrm{e}$ & 空 & $\mathrm{U}=2.33\left[\mathrm{~W} / \mathrm{m}^{2} \cdot \mathrm{K}\right], \mathrm{SC}=0.67[-](\mathrm{Low}-\mathrm{E}$ ペアガラス相当 $)$ \\
\hline |开り & $f$ & 空 & $\mathrm{U}=1.4\left[\mathrm{~W} / \mathrm{m}^{2} \cdot \mathrm{K}\right], \mathrm{SC}=0.74[-]($ 真空ガラス相当 $)$ \\
\hline & $\mathrm{g}$ & 排熱換気 & 換気回数: $10[$ 回 $/ \mathrm{h}]\left(\right.$ 室温 $24\left[{ }^{\circ} \mathrm{C}\right]$ 以上 \&外気温 $\left.20{ }^{\circ} \mathrm{C}\right]$ 以下) \\
\hline 換気 & $\mathrm{h}$ & 熱交換換気 & 熱交換効率: 70[\%] \\
\hline & $\mathrm{i}$ & 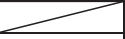 & $g+h$ \\
\hline & j & 設定温度 & 冷房: $25\left[{ }^{\circ} \mathrm{C}\right] \rightarrow 28\left[{ }^{\circ} \mathrm{C}\right]$, 暖房: $\left.21\left[^{\circ} \mathrm{C}\right] \rightarrow 200^{\circ} \mathrm{C}\right]$ \\
\hline 運用 & $\mathrm{k}$ & 冷暖房期間 & 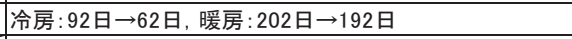 \\
\hline & 1 & 2 & $j+k$ \\
\hline 総合 & $\mathrm{m}$ & $>$ & $d+f+i+1$ \\
\hline
\end{tabular}

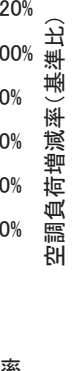

図21 空調負荷削減効果 
全て総合（m）した場合, 約 50[\%]の削減効果を期待することがで き, 積雪寒冷地地域における優先すべき対策が示唆された.

\section{5.まとめ}

積雪寒冷地域におけるCVSの店内温熱環境及び電力消費特性を明ら かにすることを目的とし，以下に示寸知見が得られた。

1）建築・設備仕様や運用状況を統計的に整理し, 断熱・開口仕様で は全国画一の標準仕様が幅広く適用され，運転モードでは特に中間 期に各店舗で大きな違いが見られた。

2）独立店舗（n=102）を対象とした2009年度の年間電力消費量は平均 で $1034\left[\mathrm{kWh} / \mathrm{m}^{2}\right.$ ・年 $]$, 店舗間の差は最大で $487\left[\mathrm{kWh} / \mathrm{m}^{2}\right.$ ・年], 築 8 年以下 では年数に応じて電力消費量の増加が確認された。

3）電力消費量に対する要因分析に基づくCVSの電力消費予測モデル を作成し, 独立店舗を対象とした年間及び月間（冬期）の重回帰式 では予測精度が比較的高かった。

4） CVS特有の商品管理上の各設定温度や空調方式等の違いが及ぼす 温度分布への影響を分析し, 店舗 $\mathrm{N}$ 温度差は $8\left[{ }^{\circ} \mathrm{C}\right]$ 前後かつ最大で $10\left[{ }^{\circ} \mathrm{C}\right]$ 以上, 店舗 $\mathrm{S}$ 温度差は $5\left[{ }^{\circ} \mathrm{C}\right]$ 前後であることが確認された。

5）CVS特有の電力消費比率を示し, 系統別では動力系が僅かに上回 り, 分類別では空調が全体に影響を与え, 機能別では必要機能が全 体の $2 / 3$ 程度を占めることがわかった.

6） CVS特有の年間エネルギー消費原単位を示し，店舗Nは独立店舗の 平均的な消費原単位, 店舗Sはその3割減に位置しており, CVSの消費 量は住宅の8～10倍，消費原単位は5〜7倍に相当していた。

7）CVSに適用可能なエネルギー効率の評価方法を提案し, 全体PUE-C は季節に応じて変動しながら $1.2 \sim 1.70$ 範囲になり, これを基に各 店舗で必要なエネルギー削減に向けた対策が明確になる。

8）地域性と実行性を考慮した上で，空調負荷に焦点を当てて建築的 対応かつ運用改善による削減効果を定量化し，各対策を全て総合し た場合，約50[\%]の削減効果を期待することができる.

\section{謝辞}

平成22２3年度科学研究費補助金（若手研究（B））「地域性と実 行性を考虑した環境配慮型コンビニエンスストアの開発」（研究代 表者: 菊田弘輝）, 平成 22 年度財団法人トステム建材産業振興財団 研究助成「積雪寒冷型コンビニエンスストアにおける建築的対応に よる熱負荷低減手法の検討」（申請者：菊田弘輝）を受けて本研究 を実施しました。また，森セブンーイレブン・ジャパン（株KGプラン ニング，北海道ガス侏には多大なご協力を頂きました，記して謝意 を表します。
注

注1）期間中の電力消費量の最大誤差（=実測値一メーター指針値）は店舗 N （2009/11〜2010/10）では155[kWh/月]，店舗S（2010/11〜2011/10）では $79[\mathrm{kWh} /$ 月]となり, これは全体の1[\%]未満に相当し, 測定精度に問題は ないと判断した.

注2）№. 15, 16, 18, 21の天井吹出し口は循環ファン用，№. 22の空調吹出し口は ルームエアコンである

注3）店舗オーナーや従業員に通常勤務を要請したが, 東日本大震災の影響で 2011/3/11 2011/3/31に亘って全店舗に節電要請が為され，その後は各店 舗で自主的に節電を心掛けている。

注4）必要機能と一般機能の仕分けはCVS各社で当然異なるが，基本的に必要機 能にはCVS本来の商品管理及び販売に関するものとする。

注5）PUE-Cとは, Power Usage Effectiveness for Convenience Storeの略称で ある。

注6）動力系PUE-C $=$ CVS 全体の動力系の電力消費量/CVS内の動力系の必要機能 の電力消費量（主に空調の省エネ化指標） 電灯系PUE-C $=$ CVS 全体の電灯系の電力消費量 $/ C V S$ 内の電灯系の必要機能 の電力消費量（主に照明の省エネ化指標）

\section{参考文献}

1）社団法人 日本フランチャイズチェーン協会 : コンビニエンスストア統計 調查月報 2011年11月度，2011. 12

2）一般社団法人 日本サステナブル建築協会 : 非住宅建築物の環境関連デー タベース検討委員会 平成21年度 報告書，907頁，2010.3

3）齋藤卓磨ら：非住宅（民生業務部門）建築物の環境関連データベース構築 に関する研究 その 45 関東地方のコンビニにおけるエネルギー消費の傾向 に関する研究（平成21年度調查），日本建築学会大会学術講演梗概集 環 境工学 I, pp. 1161-1162, 2010.9

4）鈴木雄介ら : 非住宅（民生業務部門）建築物の環境関連データベース構築 に関する研究 その 72 小売店舗の業態別エネルギー消費特性の分析, 日本 建築学会大会学術講演梗概集 環境工学 I, pp. 1009-1010，2011.8

5）中野隆司，坂本雄三 : コンビニエンスストアの省エネルギー化に関する 研究 エネルギー消費特性に関する実測調査, 日本建築学会大会学術講 演梗概集 環境工学 II ，pp. 191-192，2004.8

6）中野隆司, 瓦口泰一, 坂本雄三, 小林雅和 : コンビニエンスストアの省 エネルギー化に関する研究 その 2 制御導入前・導入後のCVS空調消費電 力量予測モデルの作成, 日本建築学会大会学術講演梗概集 環境工学 II , pp. 359-360, 2005. 9

7）瓦口泰一, 中野隆司, 坂本雄三, 小林雅和 : コンビニエンスストアの省 エネルギー化に関する研究 その 3 CVS空調消費電力量予測モデルを利用 した建物仕様検討, 日本建築学会大会学術講演梗概集 環境工学 II, pp. 361-362, 2005.9

8）鈴木直樹，小松義典：小型物販コンビニエンスストアのファサードデザ インが泠暖房負荷に及ぼす影響, 日本建築学会東海支部研究報告集 No. 43 , pp. 381-384，2005. 2

9）福井智浩，小松義典：小型物販施設における周辺建物の影響を考慮した 太陽光発電可能量の検討, 日本建築学会大会学術講演梗概集 環境工学 II ， pp. 1315-1316，2010.9

10）侏住環境計画研究所：家庭用エネルギーハンドブック，2009

11) http://www. thegreengrid. org/Global/Content/white-papers/TheGreen-Grid-Data-Center-Power-Efficiency-Metrics-PUE-and-DCiE, 2012.1. 㧁照

（2012年 1 月 6 日原稿受理，2012年 4 月 4 日採用決定） 